\title{
Czy wskaźnik masy ciała i stężenie lipidów w surowicy wpływają na częstość występowania i przebieg migreny?
}

\section{Body mass index and serum lipid levels in effect on the incidence and course of migraine}

\author{
Kamil Chorążka, Marlena Janoska, Paweł Świć, lzabela Domitrz
}

Katedra i Klinika Neurologii, Warszawski Uniwersytet Medyczny

Neurologia i Neurochirurgia Polska 2013; 47, 6: 572-576

DOI: 10.5114/ninp.2013.39075

\section{Streszczenie}

Migrena to choroba znana wielu specjalistom i mająca charakterystyczny obraz kliniczny. Ostatnie badania wskazują na czynniki ryzyka związane z częstszym zachorowaniem na to schorzenie. Dużo miejsca poświęcono potencjalnemu wpływowi nieprawidłowego wskaźnika masy ciała (BMI) oraz nieprawidłowych wartości profilu lipidowego na występowanie i przebieg migreny. Zważywszy że czynniki te mają również związek z częstszym występowaniem chorób układu krążenia, niektóre prace starają się wytłumaczyć istnienie takiego podwyższonego ryzyka u chorych na migrenę. Sugeruje się związek pomiędzy nieprawidłowym BMI a ryzykiem zachorowania na migrenę i bardziej nasilonym przebiegiem tych bólów. $Z$ kolei w badaniach dotyczących profilu lipidowego w migrenie najczęstszym odchyleniem okazują się zwiększone stężenia cholesterolu całkowitego i frakcji LDL. Wykazano zależność między ryzykiem wystąpienia migrenowych bólów głowy a stężeniem cholesterolu całkowitego i frakcji LDL. W większości badań nie stwierdzono wpływu frakcji HDL i triglicerydów na migrenę. Autorzy przedstawiają najnowsze spojrzenie na problem BMI i stężeń lipidów u chorych na migrenę.

Słowa kluczowe: migrena, BMI, lipidy, cholesterol, triglicerydy, choroby układu krążenia.

Migrena to często spotykane schorzenie neurologiczne, występujące częściej u kobiet. Choroba ta powoduje nawracające epizody bólów głowy wpływające de struktywnie na życie pacjentek [1]. Migrenę dzieli się

\begin{abstract}
Migraine is a well-known condition for many medical specializations. Some authors evaluate the potential impact of the abnormal body mass index (BMI) and abnormal lipid profile on the vulnerability to migraine and its severity. Regarding the fact that these factors have the inseparable connection with the risk of cardiovascular diseases, some papers bring the hypotheses of the probable role of migraine in the progression of such conditions. Some research suggests a link between abnormal BMI and a risk of migraine and its more severe course. When it comes to a lipid panel in migraine, the most frequent abnormalities are elevated levels of total cholesterol and low-density lipoprotein cholesterol which may contribute to the increased risk of migraine. High-density lipoprotein and triglycerides levels were not contributory in most of the papers. We present the latest views on the mentioned problems focusing on differences in results of the particular works.
\end{abstract}

Key words: migraine, BMI, lipids, cholesterol, triglycerides, cardiovascular diseases.

na dwa podtypy: migrenę bez aury i migrenę $\mathrm{z}$ aurą ta druga dotyka nawet ok. 30\% chorych [2]. Uważa się, że występowanie migreny jest związane zarówno z czynnikami genetycznymi (nawet do 65\% [3-5]), jak i śro-

Adres do korespondencji: Izabela Domitrz, Katedra i Klinika Neurologii, Warszawski Uniwersytet Medyczny, ul. Banacha 1 A, 02-097 Warszawa, Polska, tel.: +482259928 57, faks: +482259918 57, e-mail: izabela.domitrz@wum.edu.pl

Pracę otrzymano: 28.09.2012; przyięto do druku: 23.01.2013 
dowiskowymi [6]. Spośród czynników środowiskowych ważną grupę stanowią te przyczyniające się do zwiększonego ryzyka wystąpienia chorób układu krążenia, przede wszystkim udaru mózgu $[7,8]$, choroby wieńcowej i zawału serca [8-10]. Okazuje się bowiem, że u osób chorujących na migrenę ryzyko to jest zwiększone, choć niektórzy autorzy podkreślają, że dotyczy ono tylko migreny $z$ aurą $[8,11]$. Hamed i wsp. zauważyli, że u osób chorych na migrenę występuje zwiększone stężenie endoteliny 1 oraz nieprawidłowa reakcja naczyniowa zależna od endotelin. Reakcję tę oceniono na podstawie rozszerzenia wywołanego przepływem (flow-mediated dilation) $\mathrm{w}$ tętnicy ramiennej w trakcie przekrwienia. Autorzy stwierdzili też zwiększenie grubości kompleksu błony środkowej i wewnętrznej tętnic szyjnych (carotid artery intima-media thickness - CA-IMT). Wszystkie te wyniki były charakterystyczne dla zwiększonego ryzyka miażdżycy, a co za tym idzie - chorób układu krążenia [12]. Besir i wsp. [13] potwierdzili występowanie nieprawidłowej CA-IMT u chorych na migrenę.

Kolejne prace podejmują temat korelacji nieprawidłowego wskaźnika masy ciała (body mass index - BMI) oraz zwiększonych stężeń lipidów w osoczu, czyli czynników związanych ze zwiększonym ryzykiem rozwoju chorób naczyniowych u pacjentów z migreną.

\section{Wskaźnik masy ciała a migrena}

Zależność pomiędzy BMI a bólami migrenowymi jest kontrowersyjna. Dostępne prace skupiają się głównie na obserwacji ryzyka wystąienia tej choroby w populacji osób z nieprawidłowym BMI oraz próbie zwrócenia uwagi na wpływ tego czynnika na przebieg migreny. W jednym $z$ publikowanych badań 27 kobiet ze średnim BMI 41,07 zakwalifikowano do zabiegu bariatrycznego. Oceniono u nich częstość występowania bólów głowy. Siedemnaście spośród nich cierpiało na sporadyczne bóle głowy, 13 było chorych na migrenę (w tym 10 miało migrenę z aurą). U kolejnych czterech pacjentek rozpoznano ból głowy typu napięciowego. Mimo małej grupy badanej warto podkreślić, że wśród kobiet bardzo otyłych stwierdzono duży odsetek osób z bólami głowy [14]. W innym badaniu u 3733 kobiet we wczesnej ciąży (opieka położnicza do 20. tygodnia po poczęciu) przeprowadzono ankietę dotyczącą ich masy ciała $i$ wzrostu w wieku 18 lat i na 3 miesiące przed poczęciem. Następnie przeprowadzono u nich wywiad migrenowy. Okazało się, że kobiety z nieprawidłowo dużym BMI miały zwiększone ryzyko wystąpienia migreny. Dodatkowo udowodniono, że osoby z wywiadem migreny w dzieciństwie (rozpoznanie przed 18. rokiem życia) miały zwiększone ryzyko co najmniej dziesięciokilogramowego przyrostu masy ciała w porównaniu z osobami bez tej choroby. Wskazywałoby to na wtórną obecność otyłości w migrenie, czego inne projekty badawcze nie potwierdzają [15]. Niektóre prace $[14,15]$ wskazują na zależność między otyłością i zwiększonym ryzykiem wystąpienia migreny. $Z$ kolei Winter i wsp. ocenili bardzo dużą grupę 63467 uczestników, z których 12613 zgłaszało migrenowe bóle głowy, w tym 9195 migrenę aktywną, czyli epizod bólowy spełniający kryteria rozpoznania migreny, w poprzednim roku. W przypadku kobiet z BMI większym niż 35 stwierdzono zwiększone ryzyko wystąienia migreny. Jednakże ryzyko takie statystycznie było istotne już u kobiet z BMI powyżej 30. Co ważniejsze, w analizie wieloczynnikowej biorącej pod uwagę palenie papierosów, nadciśnienie tętnicze, ćwiczenia fizyczne i spożycie alkoholu zależność ta nie była już tak wyraźna. Częstsze bóle głowy występowały u kobiet z BMI powyżej 35, jak również z BMI poniżej 23. Kobiety otyłe były bardziej narażone na fonofobię, fotofobię, jednak rzadziej na ból jednostronny i objawy aury [16]. W innej pracy Ford i wsp. [17] podają, że ciężkie bóle głowy oraz bóle migrenowe mogą się pojawić u pacjentek z BMI mniejszym niż 18,5 oraz większym niż 30. Jeszcze inne obserwacje przedstawili Le i wsp. [18] - migrena występowała częściej tylko u osób z niedowagą, a nadmierna masa ciała zmniejszała częstość występowania tej choroby [18]. Warto pamiętać o badaniach całkowicie negujących jakikolwiek wpływ BMI na występowanie i przebieg migreny. Mattsson opisał 684 pacjentki w wieku 40-74 lat, które zgłosiły się na przesiewowe badanie mammograficzne. Oceniano u nich wzrost i masę ciała. Kobiety, które nigdy nie miały migreny, nie różniły się pod względem BMI od tych, które chorowały na migrenę $(p=0,96)$. Kobiety otyłe z migreną w porównaniu $\mathrm{z}$ kobietami cierpiącymi na migrenę o prawidłowej masie ciała nie wykazywały statystycznie istotnych różnic w częstości napadów, czasie ich trwania czy ciężkości [19]. Téllez-Zenteno i wsp. zebrali 1371 chorych na migrenę i 612 osób stanowiących grupę kontrolną. Grupę kontrolną utworzono z ochotników honorowych dawców krwi. Udział kobiet w obu grupach był podobny. W grupie osób z migreną zaobserwowano większy odsetek chorych z nadwagą $(38,3 \%)$ w porównaniu $z$ grupą kontrolną $(33,7 \%)$. W grupie kontrolnej znajdowało się jednak więcej osób z otyłością $(13,6 \%$ w porównaniu z 10,3\%) i chorobliwą otyłością $(4,2 \%$ 
w porównaniu z 3,4\%). Wśród osób z migreną nie zauważono żadnej korelacji BMI z ciężkością migreny, stopniem niesprawności lub aurą. Autorzy sugerowali, że na wyniki ich pracy mogło mieć wpływ wykluczenie z analizy osób z codziennym bólem głowy. Zaobserwowano natomiast istotny statystycznie związek między nadwagą a występowaniem fotofobii [20]. Ciekawe wyniki przedstawili Bigal i wsp., którzy wykazali, że występowanie migreny nie jest związane ze zwiększonym BMI, jednak wskaźnik ten wpływa na częstość epizodów, ciężkość choroby, fonofobię i fotofobię. Ocenili 30215 chętnych na podstawie zebranego telefonicznie wywiadu. Sześćdziesiąt pięć procent badanych stanowiły kobiety, których średnia wieku wyniosła 38,4 roku [21]. Należy zaznaczyć, że BMI obliczono na podstawie podanych przez uczestników badania wzrostu i masy ciała, co może nieco różnić się od faktycznych wartości [22].

Za podstawę rozważań nad molekularnym charakterem związku między otyłością i cięższym przebiegiem migreny można by przyjąć powiązanie otyłości ze stanem zapalnym ustroju i zwiększonym stężeniem peptydu zależnego od genu dla kalcytoniny (calcitonin gene-related peptide - CGRP) lub przynajmniej ze zwiększonac wrażliwością ustroju na ten czynnik, który może zmniejszyć próg aktywności układu trójdzielno-naczyniowego. Recober i wsp. [23] sugerują rolę CGRP w wywoływaniu napadów migreny. Stwierdza się także występowanie wariantu C677T genu MTHFR (gen reduktazy metylotetrahydrofolianu), który jest kojarzony ze zwiększonym stężeniem we krwi homocysteiny, będącej potencjalnym czynnikiem ryzyka pojawienia się migreny. Homozygoty wariantu C677T genu MTHFR występowały natomiast częściej u chorych na migrenę $\mathrm{z}$ aurą i drożnym otworem owalnym, będącym kolejnym przypuszczalnym czynnikiem przyczyniającym się do rozwoju bólów migrenowych [24,25].

$\mathrm{W}$ innych badaniach autorzy doszukują się w zależności między nieprawidłowym BMI a migreną wpływu tego pierwszego na przechodzenie postaci epizodycznej migreny w migrenę przewlekłą. Scher i wsp. obserwowali grupę 1134 osób, które miały tak dużą liczbę epizodów bólowych w ciągu roku, że mogły się one przekształcać w przewlekły codzienny ból głowy (> 180 epizodów bólowych), grupę kontrolną stanowiło 789 osób (liczba epizodów bólowych w tej grupie wynosiła 2-104 w ciagu roku). Czas obserwacji obejmował 11 miesięcy. W pracy tej szacowano wpływ różnych czynników i otyłość okazała się ważnym czynnikiem ryzyka przewlekłego codziennego bólu głowy [26]. Kolejne prace oceniają spadek masy ciała i jego wpływ na przebieg bólów migrenowych. Bic i wsp. [27] w czasie 12-tygodniowej obserwacji oceniali wpływ zmniejszenia przyjmowania tłuszczów w diecie (stopniowe zmniejszanie ich ilości ustalono w przeciągu pierwszych 28 dni) na częstość, nasilenie, długość trwania oraz konieczność przyjmowania leków u chorych na migrenę. Zauważono odwrotną korelację ilości przyjmowanych tłuszczów z częstością występowania bólów głowy. Verrotti i wsp. [28] zaproponowali dłuższy, 12-miesięczny program badawczy składający się z diety niskokalorycznej, ćwiczeń fizycznych i treningu behawioralnego, który w grupie pacjentów w wieku 14-18 lat cierpiących na migrenę spowodował mniejszą częstość bólów głowy, mniejsze nasilenie napadów oraz zużycie leków w trakcie napadu i mniejszy stopień niepełnosprawności.

\section{Lipidy a migrena}

W badaniach nad stężeniami lipidów w migrenie najczęściej można zaobserwować korelację między stężeniem lipidów w osoczu a ryzykiem wystąpienia migreny i jej nasileniem. Gruber i wsp. przeanalizowali dane 136 osób. Autorzy zauważyli u pacjentów z prawidłowym BMI statystycznie istotne zwiększenie stężenia cholesterolu całkowitego (TC), frakcji LDL cholesterolu (LDL) oraz frakcji oksydowanego cholesterolu LDL. Natomiast triglicerydy (TG), cholesterol frakcji HDL (HDL) i wykładniki odpowiedzi zapalnej, takie jak białko C-reaktywne (C-reactive protein - CRP), czynnik martwicy nowotworów (tumor necrosis factor - TNF), interferon $\beta$ (INF- $\beta$ ) oraz interleukiny (IL) $6,1,8$ oraz 10 , nie przekraczały górnych wartości stężeń w osoczu. W grupie kontrolnej osób otyłych występowało zmniejszone stężenie HDL i zwiększone stężenie TG oraz czynników zapalnych, czego nie stwierdzono w grupie chorych na migrenę o prawidłowym BMI. Ostatnie porównanie dotyczyło pacjentów otyłych z migreną i bez migreny. Wyniki badań były zbliżone w obu grupach. Obejmowały zwiększone stężenia TC, LDL, oksydowanego LDL, TG i wykładników stanu zapalnego oraz zmniejszone stężenie HDL. Wyniki te wyraźnie wskazują na nieprawidłowy profil lipidowy u osób z migreną i prawidłową masą ciała, niezależnie od tego, czy jest to migrena $z$ aurą czy nie, przy czym nieprawidłowości dotyczyły tylko zwiększonych stężeń TC i LDL. Wartości TG nie były zwiększone, a stężenie HDL zmniejszone, w przeciwieństwie do osób otyłych. Wykazano, że oksydowany LDL jest związany ze zwiększonym ryzykiem zachorowania na migrenę - czynnik ryzyka migreny u chorych ze średnim BMI 21,5. U osób otyłych chorych na migre- 
nę stężenia CRP i IL-6 były zwiększone [29]. Problem oksydowanego LDL zbadali również Serap i wsp. [30], uzyskując taki sam wniosek końcowy. Holenderskie badanie (The Genetic Epidemiology of Migraine - GEM) przeprowadzono w grupie liczącej 5755 osób (48\% mężczyzn) w wieku 20-65 lat, z czego wyłoniono 620 chorych na migrenę. Scher i wsp. wskazują na obecność niekorzystnego profilu lipidowego u pacjentów z migreną z aurą, czyli zwiększone stężenie TC wynoszące co najmniej $240 \mathrm{mg} / \mathrm{dl}[\mathrm{OR}=1,43(0,97-2,1)]$, a stosunek TC do HDL większy niż 5,0 [OR = 1,64 $(1,1-2,4)]$. Migrena z aurą implikowała podwójnie zwiększone ryzyko podwyższonego wyniku w skali Framingham ogólnego ryzyka sercowo-naczyniowego i zmniejszenia stężenia HDL [31]. Kurth i wsp. zbadali grupę liczącą 27626 kobiet w wieku 45 lat i powyżej, z których 5087 zgłaszało migrenę aktywną (ból migrenowy w ostatnim roku) lub migrenowe bóle w przeszłości. Zauważyli oni, że kobiety, które potwierdziły wywiad w kierunku migreny, miały statystycznie istotnie zwiększone stężenia takich substancji, jak TC, LDL, nie-HDL, ApoB100, CRP, ICAM-1, i zmniejszone stężenie HDL. Różnica wyników pomiędzy grupą badaną i kontrolną była jednak tak mała, że autorzy podają w wątpliwość tezę o jej wpływie na większe ryzyko występowania chorób układu krążenia. Zwiększone stężenia nie korelowały z częstością bólów głowy. Należy natomiast zwrócić uwagę, że migrenę $\mathrm{z}$ aurą lub bez aury rozpoznawano $\mathrm{u}$ tych pacjentek na podstawie wypełnionej przez nie ankiety, co może nie być zgodne z rzeczywistością [32]. Niektórzy autorzy podjęli temat lipidów u starszych pacjentów z migreną. Monastero i wsp. na podstawie kwestionariusza oceniającego występowanie chorób neuropsychiatrycznych u osób powyżej 50. roku życia wśród 1809 probandów (151 osób chorowało na migrenę) udowodnili, że stężenie TC i LDL jest istotnie zwiększone w grupie chorych na migrenę. Dodatkowo u osób z większym stężeniem TC stwierdzono większe ryzyko wystąpienia migreny (najbardziej wyrażone u starszych mężczyzn) [33]. Natomiast Rist i wsp. zbadali 1155 osób, z czego 166 pacjentów podawało migrenę w wywiadach, w tym 23 - migrenę $\mathrm{z}$ aurą, a 64 uczestników badania zgłaszało inne rodzaje bólów głowy. Stwierdzili oni, że TC oraz TG są związane $\mathrm{z}$ występowaniem migreny, ale tylko $\mathrm{z}$ aurą, również u osób starszych [34]. Opisywane zależności można wyjaśnić polimorfizmem receptora LDL (LDLR). Mochi i wsp. zauważyli, że polimorfizm LDLR (19p13.2) koreluje z częstszym występowaniem migreny bez aury [35], co nie zgadza się z wynikami Curtaina i wsp., którzy takich zależności nie odnotowali [36].
Inną ciekawą częścią badania Mochi i wsp. była ocena związku stężeń TC, TG, LDL, HDL z występowaniem migreny. Nie uzyskano istotności statystycznej, jednak w tej pracy opisywano grupę osób zamieszkujących wyspę Norfolk położoną na Oceanie Spokojnym, gdzie charakterystyka genetyczna i środowiskowa niewiele różni się pomiędzy mieszkańcami tego regionu.

\section{Podsumowanie}

Na podstawie piśmiennictwa można wnioskować, że czynniki ryzyka, takie jak nadmierna masa ciała oraz stężenie lipidów w osoczu, mają wpływ na przebieg i występowanie migreny. Do końca nie można jednoznacznie określić takiego związku, aczkolwiek dużo artykułów wskazuje na istnienie zależności między tymi wskaźnikami a migreną. Kolejne badania wydają się nieodzowne w celu zrozumienia mechanizmów rządzących tym zjawiskiem i doprecyzowania jego znaczenia klinicznego, aby w przyszłości można było wyraźnie określić wykorzystanie tej wiedzy w praktyce. Bardziej wnikliwa analiza zależności BMI i występowania migreny mogłaby ułatwić odpowiedź na pytanie, czy nieprawi dłowa masa ciała $u$ chorych na migrenę jest zjawiskiem pierwotnym czy też może wywołanym przez same bóle głowy, jak twierdzą Vo i wsp. [15]. Wyjaśnienie tego zagadnienia mogłoby pomóc w określeniu, czy profilaktyka chorób układu krążenia w migrenie jest bardziej skuteczna poprzez utrzymanie właściwej masy ciała czy może bardziej istotnym elementem okazałaby się tutaj kontrola samego przebiegu bólów głowy. Taka obserwacja mogłaby być przydatna także w określeniu znaczenia profilu lipidowego w migrenie. Warto wspomnieć również, że istnieją inne, bardziej relewantne wyznaczniki ryzyka chorób układu krążenia, takie jak wartość obwodu w pasie na wysokości pępka i zawartość procentowa tłuszczu w jamie brzusznej, o których powinno się pamiętać, planując kolejne projekty naukowe oceniające czynniki ryzyka wspólne dla migreny i chorób układu krążenia. Niemniej warto pamiętać, że mimo wyjaśnienia tych skomplikowanych zjawisk utrzymanie prawidłowego BMI i stężenia lipidów w osoczu jest ważnym elementem profilaktycznym innych chorób i należy zachęcać pacjentów do regularnej kontroli ich wartości.

\section{Oświadczenie}

Autorzy zgłaszają brak konfliktu interesów. 


\section{Pišmiennictwo}

1. Lipton R.B., Stewart W.F., Diamond S. i wsp. Prevalence and burden of migraine in the United States: data from the American Migraine Study II. Headache 2001; 41: 646-657.

2. Launer L.J., Terwindt G.M., Ferrari M.D. The prevalence and characteristics of migraine in a population-based cohort: the GEM study. Neurology 1999; 53: 537-542.

3. Gervil M., Ulrich V., Kaprio J. i wsp. The relative role of genetic and environmental factors in migraine without aura. Neurology 1999; 53: 995-999.

4. Mulder E.J., Van Baal C., Gaist D. i wsp. Genetic and environmental influences on migraine: a twin study across six countries. Twin Res 2003; 6: 422-431.

5. Ulrich V., Gervil M., Kyvik K.O. i wsp. The inheritance of migraine with aura estimated by means of structural equation modelling. J Med Genet 1999; 36: 225-227.

6. Le H., Tfelt-Hansen P., Skytthe A. i wsp. Association between migraine, lifestyle and socioeconomic factors: a population-based cross-sectional study. J Headache Pain 2011; 12: 157-172.

7. Kurth T., Slomke M.A., Kase C.S. i wsp. Migraine, headache and the risk of stroke in women: a prospective study. Neurology 2005; 64: 1020-1026.

8. Kurth T., Gaziano J.M., Cook N.R. i wsp. Migraine and risk of cardiovascular disease in women. JAMA 2006; 296: 283-291.

9. Bigal M.E., Kurth T., Hu H. i wsp. Migraine and cardiovascular disease: possible mechanisms of interaction. Neurology 2009; 72: 1864-1871.

10. Winsvold B.S., Hagen K., Aamodt A.H. i wsp. Headache, migraine and cardiovascular risk factors: The HUNT Study. Eur J Neurol 2011; 18: 504-511.

11. Elliott D. Migraine and stroke: current perspectives. Neurol Res 2008; 30: 801-812.

12. Hamed S.A., Hamed E.A., Ezz Eldin A.M. i wsp. Vascular risk factors, endothelial function and carotid thickness in patients with migraine: relationship to atherosclerosis. J Stroke Cerebrovasc Dis 2010; 19: 92-103.

13. Besir F.H., Koçer A., Dikici S. i wsp. The evaluation of atherosclerosis in migraine patients. Pain Pract 2013; 13: 41-45.

14. Horev A., Wirguin I., Lantsberg L. i wsp. A high incidence of migraine with aura among morbidly obese women. Headache 2005; 45: 936-938.

15. Vo M., Ainalem A., Qiu C. i wsp. Body mass index and adult weight gain among reproductive age women with migraine. Headache 2011; 51: 559-569.

16. Winter A.C., Berger K., Buring J.E. i wsp. Body mass index, migraine, migraine frequency and migraine features in women. Cephalalgia 2009; 29: 269-278.

17. Ford E.S., Li C., Pearson W.S. i wsp. Body mass index and headaches: findings from a national sample of US adults. Cephalalgia 2008; 28: 1270-1276.

18. Le H., Tfelt-Hansen P., Skytthe A. i wsp. Association between migraine, lifestyle and socioeconomic factors: a population-based cross-sectional study. J Headache Pain 2011; 12: 157-172.

19. Mattsson P. Migraine headache and obesity in women aged 40-74 years: a population-based study. Cephalalgia 2007; 27: 877-880.
20. Téllez-Zenteno J.F., Pahwa D.R., Hernandez-Ronquillo L. i wsp. Association between body mass index and migraine. Eur Neurol 2010; 64: 134-139.

21. Bigal M.E., Liberman J.N., Lipton R.B. Obesity and migraine: a population study. Neurology 2006; 66: 545-550.

22. Katsnelson M.J., Peterlin B.L., Rosso A.L. i wsp. Self-reported vs measured body mass indices in migraineurs. Headache 2009; 49: 663-668.

23. Recober A., Goadsby P.J. Calcitonin gene-related peptide (CGRP): a molecular link between obesity and migraine? Drug Nerws Perspect 2010; 23: 112-117.

24. Szczygioł D., Motta E., Gołba A. i wsp. Frequency of the C677T variant of the methylenetetrahydrofolatereductase (MTHFR) gene in patients with migraine with or without aura - a preliminary report. Neurol Neurochir Pol 2012; 46: 443-449.

25. Łukasik M., Kozubski W. Cryptogenic stroke - patent foramen ovale - migraine with aura: incidental triad or significant relationship? Part II. Neurol Neurochir Pol 2012; 46: 169-175.

26. Scher A.I., Stewart W.F., Ricci J.A. i wsp. Factors associated with the onset and remission of chronic daily headache in a population-based study. Pain 2003; 106: 81-89.

27. Bic Z., Blix G.G., Hopp H.P. i wsp. The influence of a low-fat diet on incidence and severity of migraine headaches. $J$ Womens Health Gend Based Med 1999; 8: 623-630.

28. Verrotti A., Agostinelli S., D'Egidio C. i wsp. Impact of a weight loss program on migraine in obese adolescents. Eur J Neurol 2013; 20: 394-397.

29. Gruber H.J., Bernecker C., Pailer S. i wsp. Lipid profile in normal weight migraineurs - evidence for cardiovascular risk. Eur $J$ Neurol 2010; 17: 419-425.

30. Yıldırım S., Akar S., Kuyucu M. i wsp. Paraoxonase 1 gene polymorphisms, paraoxonase/arylesterase activities and oxidized lowdensity lipoprotein levels in patients with migraine. Cell Biochem Funct 2011; 29: 549-554.

31. Scher A.I., Terwindt G.M., Picavet H.S. i wsp. Cardiovascular risk factors and migraine: the GEM population-based study. Neurology 2005; 64: 614-620.

32. Kurth T., Ridker P.M., Buring J.E. i wsp. Migraine and biomarkers of cardiovascular disease in women. Cephalalgia 2008; 28: 49-56.

33. Monastero R., Pipia C., Cefalù A.B. i wsp. Association between plasma lipid levels and migraine in subjects aged $\geq 50$ years: preliminary data from the Zabùt Aging Project. Neurol Sci 2008; 29: 179-181.

34. Rist P.M., Tzourio C., Kurth T. Associations between lipid levels and migraine: cross-sectional analysis in the epidemiology of vascular ageing study. Cephalalgia 2011; 31: 1459-1465.

35. Mochi M., Cevoli S., Cortelli P. i wsp. Investigation of an LDLR gene polymorphism $(19 \mathrm{p} 13.2)$ in susceptibility to migraine without aura. J Neurol Sci 2003; 213: 7-10.

36. Curtain R., Lea R.A., Quinlan S. i wsp. Investigation of the lowdensity lipoprotein receptor gene and cholesterol as a risk factor for migraine. J Neurol Sci 2004; 227: 95-100. 